\title{
Evaluation of a new formulation of Bacillus thuringiensis israelensis
}

\author{
Lopes, J. ${ }^{\mathrm{a}}$, Arantes, OMN. ${ }^{\mathrm{b}}$ and Cenci, MA. ${ }^{\mathrm{c}}$

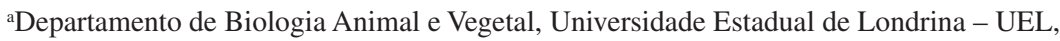 \\ CP 6001, CEP 86051-990, Londrina, PR, Brazil

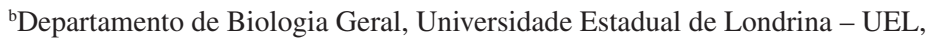 \\ CEP 86051-990, Londrina, PR, Brazil \\ 'Programa de Pós-graduação em Ciências Biológicas, Departamento de Biologia Animal e Vegetal, \\ Universidade Estadual de Londrina - UEL, CEP 86051-990, Londrina, PR, Brazil \\ *e-mail: jea@uel.br \\ Received September 28, 2009 - Accepted March 29, 2010 - Distributed November 30, 2010
}

\begin{abstract}
The aim of this study was to determine the potency (ITU) and efficacy of a liquid formulation of Bacillus thuringiensis israelensis developed by the State University of Londrina named BioUel, against early fourth instar larvae of Aedes aegypti and Culex quinquefasciatus. The ITU/mg of BioUel was 960, the $\mathrm{LC}_{50}$ was of $0.271( \pm 0.39) \mathrm{ppm}$, and the $\mathrm{LC}_{95}$ was $0.634( \pm 0.099) \mathrm{ppm}$, in larvae of $C$. quinquefasciatus. In A. aegypti larvae, $\mathrm{LC}_{50}$ was $0.332( \pm 0.042) \mathrm{ppm}$ and $\mathrm{LC}_{95}$ was $0.694( \pm 0.073) \mathrm{ppm}$. The ITU level of BioUel and its control results were similar to most commercial products tested. Stability was of approximately 90 days, which allows for local production.
\end{abstract}

Keywords: Aedes aegypti, biological control, bio-insecticide, Culex quinquefasciatus.

\section{Avaliação de um novo formulado de Bacillus thuringiensis israelensis}

\begin{abstract}
Resumo
O trabalho determinou a potência (UTI) e a eficácia de um formulado líquido de Bacillus thuringiensis israelensis desenvolvido pela Universidade Estadual de Londrina, designado como BioUel, em testes com larvas de quarto instar inicial de Aedes aegypti e Culex quinquefasciatus. A UTI/mg do Biouel foi de 960, a $\mathrm{CL}_{50}$ foi de 0,271 ( $\left.\pm 0,39\right) \mathrm{ppm}$ e a $\mathrm{CL}_{95}$, de 0,634 ( $\left.\pm 0,099\right) \mathrm{ppm}$, em larvas de $C$. quinquefasciatus. Para larvas de A. aegypti, a $\mathrm{CL}_{50}$ foi de 0,332 $( \pm 0,042)$ ppm e a $\mathrm{CL}_{95}$, de $0,694( \pm 0,073)$ ppm. A potência do BioUel e os resultados de controle foram comparáveis à maioria dos produtos comerciais testados. A estabilidade foi de aproximadamente 90 dias, o que permite uma produção local.
\end{abstract}

Palavras-chave: Aedes aegypti, controle biológico, bioinseticida, Culex quinquefasciatus.

\section{Introduction}

According to Forattini (2002), mosquito control is carried out mainly with chemical products, such as organophosphates, carbamates and pyrethroids. The utilisation of these products, however, has been limited because they are non-specific, pollute the environment, and their target insects have high rates of resistance. This situation has led to the development of biological insecticides using bacteria, fungi, viruses, and other alternative organisms (Consoli et al., 1997; Regis et al., 2001; Arantes et al., 2002; Tauil, 2002; Zequi and Lopes, 2007; Russell and Kay, 2008). The emphasis of this study is on the use of entomopathogenic bacteria of the genus Bacillus because of its high degree of specificity and environmental safety, thus particularly suitable and environmentally friendly for use in the control of insect pests.

In 1975, a new line of Bacillus thuringiensis (Bt) known as the variety israelensis (Bti) was identified and classified as serotype H-14 (Goldberg and Margalit, 1977), with high larvicidal activity for various genera of culicids and simulids. In Brazil, the use of commercial products based on $\mathrm{Bt}$ is burdensome because it must be imported and distributed. Local production would reduce costs and make it more affordable for use in the control of disease vectors; it would also promote the development of the local fermentation industry. The development of new bio-insecticide products and comparative studies with the commercially available formulations will determine the most efficient formulations and application strategies against insects.

The Londrina State University (Universidade Estadual de Londrina; UEL), in Paraná, southern Brazil, has been developing a product based on Bti, called BioUel. The research is currently at the formulation stage, and experiments 
must be conducted to determine the formulation potency in international toxic units (ITU), as well as its efficacy and shelf life.

The ITU for the liquid formulation of BioUel was calculated by bioassays using larvae of Aedes (Stegomyia) aegypti (Linnaeus, 1762) and its efficiency and stability was compared with commercial products in the laboratory, with bioassays using larvae of A. aegypti and Culex quinquefasciatus Say, 1823.

\section{Material and Methods}

\subsection{Production of the bio-insecticide}

Fermentation was carried out in a 5 litre-capacity Discovery fermenter, MRV, Incelth, France. The composition of the culture medium was as follows: $\left(\mathrm{g} . \mathrm{L}^{-1}\right)$ yeast extract, 4.0; glucose, 8.0; $\mathrm{MgSO}_{4}-7 \mathrm{H}_{2} \mathrm{O}, 0.1 ; \mathrm{KH}_{2} \mathrm{PO}_{4}$, $0.1 ; \mathrm{MnSO}_{4} .4 \mathrm{H}_{2} \mathrm{O}, 0.03 ; \mathrm{CaCl}_{2} .2 \mathrm{H}_{2} \mathrm{O}, 0.04 ;\left(\mathrm{NH}_{4}\right)_{2} \mathrm{SO}_{4}$, 0.1 . The medium was sterilised in autoclave at $120^{\circ} \mathrm{C}$ for 20 minutes. Glucose and mineral salts were sterilised separately. The $\mathrm{pH}$ was adjusted to 7.0 before sterilisation. Fermentation occurred at $30^{\circ} \mathrm{C}, 400 \mathrm{rpm}$ and aeration rate of $1.5 \mathrm{vvm}$. After sporulation, the crystal-spore mixture was filtered in a tangential filter, 40-fold concentrated (Microdyn Filter/Module MD 020 / Frings Mycrodyn) and then dried in a forced-air oven.

The liquid formulation as concentrated suspension was produced by mixing Bti primary powder with detergent, emulsifier, sun block and dispersal agents for easy scattering and slow sedimentation.

\subsection{Determination of potency}

The experiments were conducted in the Laboratory of Entomology, Department of Animal and Plant Biology, UEL, using early fourth instar larvae of $A$. aegypti and C. quinquefasciatus obtained from eggs kept at the lab insectarium.

The BioUel potency (ITU/mg) was evaluated following procedures described by WHO (1999) comparing with the International Standard IPS-82, for titration, against laboratory-reared A. aegypti larvae. A battery of bioassays was performed with five repetitions for each of six different concentrations tested and one untreated control, performed at $25 \pm 2{ }^{\circ} \mathrm{C}$. For IPS- 82 the dose consisted of $0.04,0.03$, $0.02,0.01,0.008$, and $0.005 \mathrm{mg} / \mathrm{L}$. Distilled water was added to reach $150 \mathrm{~mL}$, where $25 \mathrm{~A}$. aegypti larvae were added. For the BioUel suspension, doses were 0.5, 0.3, $0.23,0.17,0.10$ and $0.06 \mathrm{mg} / \mathrm{L}$. Initial bioassays were also conducted with the fermented solution for the determination of the adequate concentration of crystals.

Larval population densities were assessed 24 hours after treatment and data were submitted to Probit analysis (Micro Probit program) to determine the $\mathrm{LC}_{50}$ of BioUel. The potency in ITU of BioUel was calculated using the following Equation 1:

$$
\underset{\text { (test product })}{\mathrm{ITU} / \mathrm{mg}}=\frac{15.000(\mathrm{ITU} / \mathrm{mg} \text { standard }) \times \mathrm{LC}_{50}(\mathrm{mg} / \mathrm{L}) \text { of standard }}{\mathrm{LC}_{50}(\mathrm{mg} / \mathrm{L}) \text { of test product }}
$$

BioUel stability was determined by placing $500 \mathrm{~mL}$ of the product in a white opaque bottle kept in a cabinet in the laboratory, in local conditions. The bioassays were performed following the same method used in test the efficacy of BioUel, at concentrations of 0.5, 0.29, 0.22, $0.18,0.13$, and $0.10 \mathrm{ppm}$ immediately after the product was produced, and also after 30, 60, 90, 120, and 150 days. Larval population densities were assessed 24 hours after treatment. The results were submitted to Probit Analysis (Micro Probit program) to determine BioUel $\mathrm{LC}_{50}$ and $\mathrm{LC}_{95}$. The Tukey test was applied to the results obtained in the stability study.

\section{Results and Discussion}

The ITU level obtained for the new Bti formulation identified as BioUel, with A. aegypti larvae, was 960 (960 ITU/mg). BioUel has an ITU level comparable to commercial products and to products cited in the literature (Sharma et al., 2008), as shown in Table 1. For a new formulation comprising Bti, Melo-Santos et al. (2001) obtained 1146 ITU/mg, and Rodriguez et al. (1991) found 109.1 ITU/mg.

Bioassays evaluating BioUel efficacy to control C. quinquefasciatus larvae had $\mathrm{LC}_{50}$ of $0.271( \pm 0.39)$ ppm, and $\mathrm{LC}_{95}$ of $0.634( \pm 0.099) \mathrm{ppm}$ (Table 2). For A. aegypti larvae, $\mathrm{LC}_{50}$ was $0.332( \pm 0.042) \mathrm{ppm}$ and $\mathrm{LC}_{95}$ was $0.694( \pm 0.073) \mathrm{ppm}$ (Table 3$)$. These results suggest higher sensitivity in $C$. quinquefasciatus larvae. It is known that the control efficiency of insect disease vectors depends on formulation type and feeding behaviour of the mosquito larvae, in addition to the species susceptibility to the Bacillus toxin. As we applied the same formulation on species $C$. quinquelasciatus and $A$. aegypti kept in a container with less feeding space, it is supposed the LC50 and LC95 results were different for each species, due to differences in each species susceptibility.

The fermentation product was evaluated in bioassays, and the mean $\mathrm{LC}_{50}$ for $A$. aegypti larvae was $4.81 \mathrm{ppm}$ and $0.14 \mathrm{ppm}$, respectively, before and after being filtered. The mean of 0.33 ppm obtained for the BioUel (Table 3 ) shows a loss of potency of about 2.4 times, probably due to the interaction between formulation ingredients and protein crystals. A loss of 1.5 times was actually expected.

Studies to understand the lethal action of commercial or new formulations of bio-insecticides with Bti-based active principles are conducted regularly (Ibarra et al., 2003; Praça et al., 2004; Lima et al., 2005; Osborn et al., 2007). However, the target-species in experiments vary according to the mosquito species of major health concern in each region. The type of formulation used also depends on the species. This diversity makes comparison of results difficult. Rabinovitch et al. (1999) tested a new isolate of Bti, called LFB-Fiocruz 710, with an $\mathrm{LC}_{50}$ of $0.03 \mathrm{mg} / \mathrm{L}$ for Aedes albopictus (Skuse, 1894), whereas for Anopheles darlingi, Root, 1926 the $\mathrm{LC}_{50}$ was $4.8 \mathrm{mg} / \mathrm{L}$. Nayar et al. (1999) tested Vectobac ${ }^{\circledR}$ against larvae of Culex nigripalpus (Theobald, 1901) and found 0.131 and $0.208 \mathrm{ppm}$ for $\mathrm{LC}_{50}$ 
Table 1. Products containing Bacillus thuringiensis israelensis and respective potencies.

\begin{tabular}{clc}
\hline Product & \multicolumn{1}{c}{ Declared formulation potency } \\
\hline BioUel & Aqueous suspension & $960 \mathrm{ITU} / \mathrm{mg}^{(1)}$ \\
Teknar & Aqueous suspension & $3000 \mathrm{AAU} / \mathrm{mg}^{(2)}$ \\
Vectobac AS & Aqueous suspension & $1200 \mathrm{ITU} / \mathrm{mg}^{2}$ \\
Bthorus & Aqueous suspension & $1200 \mathrm{ITU} / \mathrm{mg}$ \\
\hline
\end{tabular}

(1)Aedes aegypti Units; (2)International toxic unit; Source: Vilarinhos et al., 1998 - Modified.

Table 2. Lethal concentrations $\left(\mathrm{LC}_{50}\right.$ and $\left.\mathrm{LC}_{95}\right)$ of BioUel using early fourth instar larvae of Culex quinquefasciatus at mean room temperature of $25 \pm 2^{\circ} \mathrm{C}$ and room photoperiod $(n=25$ larvae).

\begin{tabular}{lllllll}
\hline & $\begin{array}{c}\mathbf{L C}_{\mathbf{5 0}} \\
(\mathbf{p p m})\end{array}$ & $\begin{array}{c}\text { Lower } \\
\text { limit }\end{array}$ & $\begin{array}{c}\text { Upper } \\
\text { limit }\end{array}$ & $\begin{array}{c}\mathbf{L C}_{\mathbf{9 5}} \\
(\mathbf{p p m})\end{array}$ & $\begin{array}{c}\text { Lower } \\
\text { limit }\end{array}$ & $\begin{array}{c}\text { Upper } \\
\text { limit }\end{array}$ \\
\hline & 0.2743 & 0.23 & 0.3741 & 0.6557 & 0.4774 & 1.4295 \\
& 0.2044 & 0.1792 & 0.2329 & 0.497 & 0.3959 & 0.7334 \\
& 0.2937 & 0.2591 & 0.3488 & 0.647 & 0.4902 & 1.1368 \\
& 0.2817 & 0.2489 & 0.3267 & 0.5985 & 0.4698 & 0.9487 \\
& 0.3015 & 0.2621 & 0.3668 & 0.7728 & 0.5597 & 1.4773 \\
Mean & $\mathbf{0 . 2 7 1 1 2}$ & $\mathbf{0 . 2 3 5 8 6}$ & $\mathbf{0 . 3 2 9 8 6}$ & $\mathbf{0 . 6 3 4 2}$ & $\mathbf{0 . 4 7 8 6}$ & $\mathbf{1 . 1 4 5 1 4}$ \\
SD & $\mathbf{0 . 0 3 8 7 5 0 5}$ & $\mathbf{0 . 0 3 4 0 7}$ & $\mathbf{0 . 0 5 7 2 1}$ & $\mathbf{0 . 0 9 9 9 2}$ & $\mathbf{0 . 0 5 8 3 7}$ & $\mathbf{0 . 3 1 5 9 8}$ \\
\hline
\end{tabular}

$\mathrm{SD}=$ Standard deviation.

Table 3. Lethal concentrations ( $\mathrm{LC}_{50}$ and $\mathrm{LC}_{95}$ ) of BioUel using early fourth instar larvae of Aedes aegypti, at a mean room temperature of $25 \pm 2{ }^{\circ} \mathrm{C}$ and room photoperiod $(\mathrm{n}=25$ larvae).

\begin{tabular}{lcccccc}
\hline & $\begin{array}{c}\mathbf{L C}_{50} \\
(\mathbf{p p m})\end{array}$ & Lower limit & Upper limit & $\begin{array}{c}\mathbf{L C}_{\mathbf{9 5}} \\
(\mathbf{p p m})\end{array}$ & Lower limit & Upper limit \\
\hline & 0.3758 & 0.3292 & 0.4551 & 0.7527 & 0.578 & 1.2852 \\
& 0.3727 & 0.3287 & 0.4405 & 0.706 & 0.5637 & 1.0396 \\
& 0.3259 & 0.2843 & 0.3924 & 0.7345 & 0.5582 & 1.2114 \\
& 0.2823 & 0.2448 & 0.3454 & 0.7074 & 0.5159 & 1.3346 \\
& 0.301 & 0.2663 & 0.3541 & 0.5675 & 0.4601 & 0.7795 \\
Mean & $\mathbf{0 . 3 3 1 5 4}$ & $\mathbf{0 . 2 9 0 6 6}$ & $\mathbf{0 . 3 9 7 5}$ & $\mathbf{0 . 6 9 3 6 2}$ & $\mathbf{0 . 5 3 5 1 8}$ & $\mathbf{1 . 1 3 0 0 6}$ \\
SD & $\mathbf{0 . 0 4 1 9 6}$ & $\mathbf{0 . 0 3 7 6 5}$ & $\mathbf{0 . 0 4 9 4 7}$ & $\mathbf{0 . 0 7 3 1 6}$ & $\mathbf{0 . 0 4 7 9 2}$ & $\mathbf{0 . 2 2 5 6 1}$ \\
\hline
\end{tabular}

$\mathrm{SD}=$ Standard deviation

and $\mathrm{LC}_{90}$, respectively; for larvae of Aedes taenorhynchus (Wiedemann, 1821), $\mathrm{LC}_{50}$ and $\mathrm{LC}_{90}$ were respectively 0.208 and $0.374 \mathrm{ppm}$. According to these results, both species, C. nigripalpus and A. taenorhynchus, were more susceptible to the bio-insecticide than the two species used in our study, C. quinquefasciatus and A. aegypti. As they are classified in the same genera, are genetically close, and share the ability to colonise receptacles in urban areas, this comparative analysis can be allowed.

All the formulated commercial products should have a shelf life with no more than $20 \%$ potency loss (FAO and WHO, 2002). According to Thiery and Hamon (1998), the stability of IPS-82 has been regularly tested to evaluate its larvicidal activity and potency, and the yearly overall mean had a coefficient of variation lower than $20 \%$. In the present study, BioUel lost potency against $C$. quinquefasciatus and A. aegypti by 8.7 and $17.6 \%$, respectively, in the first month of storage. Five months later, the loss reached $35.4 \%$ and $26.3 \%$, respectively (Table 4 ).

Significant mean difference was observed for $\mathrm{LC}_{50}$ in the following storage months, both for A. aegypti (ANOVA, $\mathrm{F}=285.6, \mathrm{p}<0.01$ ) and $C$. quinquefasciatus (ANOVA, $\mathrm{F}=125.4, \mathrm{p}<0.02$ ). There was no significant difference in $\mathrm{LC}_{50}$ means between the second and the third months for A. aegypti larvae, and between the fourth and the fifth storage months for C. quinquefasciatus larvae (Tukey, $\mathrm{p}<0,05$ ) (Table 4). Product stability was maintained for three months. In a large country like Brazil, a product with three months of stability can be used for regional but not large scale production, for economic reasons.

So, for three months of storage, the effectiveness of BioUel is comparable to products available on the market. 
Table 4. Susceptibility of early fourth instar larvae of Culex quinquefasciatus and Aedes aegypti to BioUel stored for up to 150 days $\left(\mathrm{LC}_{50}\right.$ in $\left.\mathrm{ppm}\right)$.

\begin{tabular}{|c|c|c|c|c|}
\hline $\begin{array}{c}\text { Time } \\
\text { (days) }\end{array}$ & $\begin{array}{c}\mathrm{LC}_{50} \text { mean/SD } \\
\text { C. quinquefasciatus }\end{array}$ & $\begin{array}{c}\% \\
\text { Loss }\end{array}$ & $\begin{array}{c}\mathrm{LC}_{50} \text { mean/SD } \\
\text { A. aegypti }\end{array}$ & $\begin{array}{c}\% \\
\text { Loss } \\
\end{array}$ \\
\hline 1 & $0.21 \pm 0.013^{\mathrm{a}}$ & & $0.28 \pm 0.014^{\mathrm{a}}$ & \\
\hline 30 & $0.23 \pm 0.007^{b}$ & 8.7 & $0.34 \pm 0.001^{\mathrm{b}}$ & 17.6 \\
\hline 60 & $0.27 \pm 0.009^{c}$ & 22.2 & $0.35 \pm 0.001^{\mathrm{c}}$ & 20.0 \\
\hline 90 & $0.29 \pm 0.006^{\mathrm{d}}$ & 27.6 & $0.35 \pm 0.005^{\mathrm{c}}$ & 20.0 \\
\hline 120 & $0.31 \pm 0.006^{\mathrm{e}}$ & 32.3 & $0.36 \pm 0.007^{\mathrm{d}}$ & 22.2 \\
\hline 150 & $0.32 \pm 0.005^{\mathrm{e}}$ & 35.4 & $0.38 \pm 0.006^{\mathrm{e}}$ & 26.3 \\
\hline $\mathbf{C V}$ & 0.033209 & & 0.0128 & \\
\hline
\end{tabular}

Means followed by the same letter in same column do not differ based on Tukey's test at $5 \%$ level of significance. $\mathrm{CV}=$ Coefficient of variation.

\section{References}

ARANTES, OMN., VILAS BOAS, LA. and VILAS BOAS, GT., 2002. Bacillus thuringiensis: estratégias no contole biológico. In SERAFINI, LA., BARROS, NM. and AZEVEDO, JL. (Orgs.). Biotecnologia: Avanços na Agricultura e Agroindústria. EDUCS, v. 2, p. 269-293.

CONSOLI, RAGB., SANTOS, BS., LAMOUNIER, MA., SECUNDINO, NFC., RABINOVITCH, L., SILVA, CMB., ALVES, RSA. and CARNEIRO, NFF., 1997. Efficacy of a new formulation of Bacillus sphaericus 2362 against Culex quinquefasciatus (Diptera: Culicidae) in Montes Claros, Minas Gerais. Brazil. Memórias do Instituto Oswaldo Cruz, vol. 92, no. 4 , p. 571-573.

Food and Agriculture Organization - FAO and World Health Organization - WHO, 2002. Manual on Development and Use of FAO and WHO Specifications for Pesticides. Rome: FAOWHO, $255 \mathrm{p}$.

FORATTINI, OP., 2002. Culicidiologia Médica. São Paulo: Edusp, v. 2, 890 p.

GOLDBERG, IF. and MARGALIT, J., 1977. A bacterial spore demonstrating rapid larvicidal activity against Anopheles segentii, Uranotaenia unguiculata, Culex univitattus, Aedes aegypti and Culex pipiens. Mosquito News, vol. 37, no. 3, p. 355-358.

IBARRA, JE., RINCÓN, MC., ORDÚZ, S., NORIEGA, D., BENINTENDE, G., MONNERAT, R., REGIS, L., OLIVEIRA, CMF., HUMBERTO, LANZ., RODRIGUEZ, MH., SÁNCHEZ, G., PEÑA, G. and BRAVO, A., 2003. Diversity of Bacillus thuringiensis Strains from Latin America with Insecticidal Activity against Different Mosquito Species. Applied and Environmental Microbiology, vol. 69, no. 9, p. 5269-5274.

LIMA, JBP., MELO, NV. and VALLE, D., 2005. Persistence of Vectobac WDG and Metoprag s-2g against Aedes aegypti larvae using a semi-field bioassay in Rio de Janeiro, Brazil. Revista do Instituto de Medicina Tropical de Sao Paulo, vol. 47, no. 1, p. 7-12.

MELO-SANTOS, MAV., SANCHES, EG., JESUS, FJ. and REGIS, L., 2001. Evaluation of a new tablet formulation based on Bacillus thuringiensis serovar israelensis for larvicidal control of Aedes aegypti. Memórias do Instituto Oswaldo Cruz, vol. 96, no. 6, p. $859-860$.
NAYAR, JK., KNIGHT, JW., ALI, A., CARLSON, DB. and O'BRYAN, PD., 1999. Laboratory evaluation of biotic and abiotic factors that may influence larvicidal activity of Bacillus thuringiensis serovar israelensis against two Florida mosquito species. Journal of the American Mosquito Control Association, vol. 15 , no. 1 , p. $32-42$.

OSBORN, FR., HERRERA, MJ., GÓMEZ, CJ. and SALAZAR, A., 2007. Comparison of two commercial formulations of Bacillus thuringiensis var. israelensis for the control of Anopheles aquasalis (Diptera: Culicidae) at three salt concentrations. Memórias do Instituto Oswaldo Cruz, vol. 102, no. 1, p. 69-72.

PRAÇA, LB., BATISTA, AC., MARTINS, ES., SIQUEIRA, CB., DIAS, DGS., GOMES, ACMM., FALCÃO, R. and MONNERAT, RG., 2004. Estirpes de Bacillus thuringiensis efetivas contra insetos das ordens Lepidoptera, Coleoptera e Diptera. Pesquisa Agropecuária Brasileira, vol. 39, no. 1, p. 11-16.

RABINOVITCH, L., CAVADOS, CFG., CHAVES, JQ., COUTINHO, CJPCA., ZAHNER, V., SILVA, KRA. and SELDIN, L., 1999. A new strain of Bacillus thuringiensis serovar israelensis very active against blackfly larvae. Memórias do Instituto Oswaldo Cruz, vol. 94, no. 5, p. 683-685.

REGIS, L., SILVA-FILHA, MH., NIELSEN-Le ROUX, C. and CHARLES, JF., 2001. Bacteriological larvicides of dipteran disease vectors. TRENDS in Parasitology, vol. 17, no. 8, p. 377-380.

RODRIGUEZ, ML., MORALES, LH., TORRES, R., QUIROZ, H. and CULEBRO, M., 1991. Laboratory testing and field testing of a formulation Bacillus thuringiensis var. israelensis on Culex larvae (Diptera, Culicidae). Southwestern Entomologist, vol. 16, no. 3, p. 277-281.

RUSSELL, TL. and KAY, BH., 2008. Biologically based insecticides for the control of immature Australian mosquitoes: a review. Australian Journal of Entomology, vol. 47, p. 232-242.

SHARMA, SK., UPADHYAY, AK., HAQUE, MA., RAGHAVENDRA, K. and DASH, AP., 2008. Field evaluation of a previously untested strain of biolarvicide (Bacillus thuringiensis israelensis H14) for mosquito control in an urban area of Orissa, India. Journal of the American Mosquito Control Association, vol. 24, no. 3, p. 410-414.

TAUIL, PL., 2002. Aspectos críticos do controle do dengue no Brasil. Cadernos de Saúde Pública, vol. 18, no. 3, p. 867-871. 
THIERY, I. and HAMON, S., 1998. Bacterial control of mosquito larvae: investigation of stability of Bacillus thuringiensis israelensis and Bacillus sphaericus standart powders. Journal of the American Mosquito Control Association, vol. 14, no. 4, p. 472-476.

VILARINHOS, PTR., DIAS, JMCS., ANDRADE, CFS. and ARAÚJO-COUTINHO, CJPC., 1998. Uso de bactéria para o controle de culicídeos e simulídeos. In ALVES, SB. (Ed.). Controle Microbiano de Insetos. 2. ed. Piracicaba: FEALQ.
World Health Organization - WHO, 1999. DRAFT Guideline Specifications for Bacterial Larvicides for Public Health Use. Geneva: WHO, 37 p. Report of the WHO Informal Consultation.

ZEQUI, JAC. and LOPES, J., 2007. Biological control of Culex (Culex) saltanensis Dyar (Diptera, Culicidae), through Bacillus thuringiensis thuringiensis israelensis in laboratory and field condition. Revista Brasileira de Zoologia, vol. 24, no. 1, p. 164-168. 
